\title{
Axonal Growth and Fasciculation Linked to Differential Expression of BDNF and NT3 Receptors in Developing Cerebellar Granule Cells
}

\author{
Rosalind A. Segal, ${ }^{1,2}$ Scott L. Pomeroy, ${ }^{1,3}$ and Charles D. Stiles ${ }^{1,4}$ \\ 'Department of Cell and Molecular Biology, Dana-Farber Cancer Institute, 2Department of Neurology, Beth Israel \\ Hospital, ${ }^{3}$ Department of Neurology, Children's Hospital, and ${ }^{4}$ Department of Microbiology and Molecular Genetics, \\ Harvard Medical School, Boston, Massachusetts 02115
}

In the developing cerebellum, young granule neurons in the external germinal layer respond preferentially to BDNF, while mature neurons within the inner portion of the cerebellum respond preferentially to NT3. Here we show that this anatomic distinction reflects a developmentally regulated switch at the level of neurotrophin receptor gene expression. The salient feature of the developmental switch is a change in the ratio of mRNA transcripts encoding functional BDNF and NT3 receptor tyrosine kinases. The ratio of the BDNF receptor trkB to the NT3 receptor trkC reverses from $5: 1$ in neonatal cerebellum to $1: 3$ in adult cerebellum.

TrkB and TrkC are closely related transmembrane tyrosine protein kinases. However, activation of BDNF and NT3 receptors in cerebellar granule neurons do not give equivalent biological responses. In aggregate cell culture and single cell assays, BDNF enhances axonal outgrowth of early granule cells by influencing neurite elongation. In contrast, NT3 alters the morphology of outgrowth. Collectively, these findings suggest that regulation of neurotrophin receptors during cerebellar development is important for the timing and morphology of axonal growth.

[Key words: cerebellum, granule cells, neurotrophins, axon outgrowth, fasciculation, receptor tyrosine kinase]

Cerebellar granule cells are well suited for studying factors that control morphologic and biochemical changes during neuronal differentiation. Granule cells develop from dividing precursors in the outer portion of the external germinal layer (EGL) of the cerebellum. Within the EGL there is extensive apoptotic death of these early granule cells. The surviving cells extend short processes parallel to the pial surface and then migrate to the internal granule cell layer. The T-shape processes formed from the initial bipolar neurite become the axons of the mature gran-

\footnotetext{
Received Dec. 14, 1994; revised Feb. 8, 1995; accepted Feb. 10, 1995.

We thank Andrew Welcher of Amgen for the generous gift of neurotrophins. We thank Drs. L. Benowitz, J. Camahan, R. Hawkes, D. Kaplan, K. Kosik, and T. Roberts, for antibodies, and Drs. M. Barbacid, T. Jessell, N. Irwin, M Chao, and M. Greenberg for clones that they have generously given us. We thank A. Ghosh and M. Greenberg for helpful discussions. We thank Rebecca Gelman for help with statistical analysis, and Lori Rua for technical assistance. This work was supported by a Clinical Investigator Development Award (R.A.S) and grants from the NIH (C.D.S. GM 31489, HD 24926; S.L.P. NS27773).

Correspondence should be addressed to Dr. Charles D. Stiles, Dana-Farber Cancer Institute, 44 Binney Street, Boston, MA 02115.
}

Copyright (C) 1995 Society for Neuroscience $0270-6474 / 95 / 154970-12 \$ 05.00 / 0$ ule cells, and the neurons subsequently elaborate dendrites, and make synaptic connections (Miale and Sidman, 1961; Altman, 1972a,b; Burgoyne and Cambray-Deakin, 1988; Hatten, 1993)

We and others have shown that cerebellar neurons are responsive to neurotrophins (Segal et al., 1992; Lindholm et al., 1993; Leingartner et al., 1994). The neurotrophins are a family of related, homodimeric protein factors that includes NGF, brainderived neurotrophic factor (BDNF), neurotrophin-3 (NT3), and neurotrophin 4/5 (NT4/5) (reviewed by Barde, 1989). These factors were originally identified based on their ability to support the survival of neuronal cells (Levi-Montalcini and Angeletti, 1968; Barde et al., 1982), but subsequently have been found to have diverse effects on developing neurons in vivo and in vitro. In addition to their ability to promote cell survival and prevent apoptosis, they have also been found to influence commitment to a specific lineage (Knusel et al., 1991; Sieber-Blum, 1991) and to stimulate neurite elongation (Davies et al., 1986; Cohen et al., 1994).

Two classes of neurotrophin receptors have been identified: a low affinity receptor, $\mathrm{p75}$, and a set of high affinity receptors known collectively as the Trks. The Trks are a family of structurally related receptor tyrosine kinases, TrkA, TrkB, and TrkC (reviewed in Barbacid et al., 1991; Chao, 1992; Barbacid, 1993; Raffioni et al., 1993). Trk A serves as the high affinity receptor for NGF. Trk B is the receptor for BDNF and NT4/5. Trk C serves as the principal receptor for NT3. Activation of any Trk by formation of a complex with its cognate ligand triggers a signal transduction cascade which culnininates in induction of "immediate early genes" such as $c$-fos (reviewed in Sheng and Greenberg, 1990).

In previous work we analyzed c-Fos induction in cerebellar organotypic cultures to monitor the response to neurotrophins. Using this assay, we found that developing and mature cerebellar granule neurons are differentially responsive to neurotrophins; immature, premigratory cells respond to BDNF, while more mature cells respond preferentially to NT3 (Segal et al., 1992). These observations raised two questions. What is the molecular basis of the switch in neurotrophin sensitivity? Do cerebellar neurons display an equivalent biological response to BDNF and NT3? In this study we address this pair of issues. Our findings suggest that temporal regulation of neurotrophin receptors during development of the cerebellum is important for the timing and morphology of the growing axons.

\section{Materials and Methods}

Cerebellar cultures and granule cell preparation. Balb/c mice were obtained from JAXLab or the Dana-Farber breeding colony. Pups were 
taken at postnatal day number $2( \pm 1 \mathrm{~d})$ and euthanized by decapitation. The cerebella were rapidly removed and placed in Hanks' balanced salt solution, calcium and magnesium free (HBSS). The tissues were washed twice in HBSS, and then treated with $1 \%$ trypsin in HBSS for $1.5 \mathrm{~min}$. DME with $10 \%$ FCS was then added, and the cells were pelleted in a clinical centrifuge. The cells were washed in HBSS, then dissociated by trituration through a P-200 pipette tip. Trypan blue excluding cells were counted and used for granule cell purification, or plated as mixed cultures.

The protocol of Hatten was followed to purify granule cells (Hatten, 1985). Briefly, dissociated cerebellar cells were layered over a step gradient of Percoll ( $2 \mathrm{ml}$ of $65 \%$ Percoll in HBSS, $2 \mathrm{ml}$ of $35 \%$ Percoll in HBSS, and then $2 \mathrm{ml}$ of cell suspension). The gradient was spun in a clinical centrifuge at $4500 \mathrm{rpm}(2000 \times \mathrm{g})$ for $20 \mathrm{~min}$. The gradient was then divided into thirds. The middle third, which contained the granule cells, was plated in DME with $10 \%$ FCS on a tissue culture dish treated with polylysine $(25 \mu \mathrm{g} / \mathrm{ml}$ for $30 \mathrm{~min})$ to remove the adherent glial cells. The medium containing the non-adherent cells was centrifuged. Finally, the pelleted granule cells were resuspended in HBSS. For some experiments a second cycle of purification was done; the purified cell preparation was again fractionated on a Percoll gradient, and the middle fraction was again plated on polylysine. The granule cell preparations were assessed by analyzing the percentage of cells positive for Q600 (a granule cell marker) (Hawkes, 1992), GFAP (a glial cell marker) and calbindin (a Purkinje cell marker) (Jande et al., 1981). The single cycle preparations were $90-95 \%$ granule cells by these criteria, while the two cycle preparations were $95-99 \%$ granule cells.

The isolated cerebellar cells were plated on tissue culture surface treated with polyornithine $(15 \mu \mathrm{g} / \mathrm{ml})$, in DME with $10 \mathrm{mM}$ HEPES and $10 \%$ FCS. Four hours after plating, the serum containing media was removed and replaced with the serum-free medium N2 (Bottenstein, 1985) supplemented with $0.1 \mathrm{mg} / \mathrm{ml} \mathrm{BSA}$, and $20 \mathrm{~mm} \mathrm{KCl}$ to improve granule cell viability.

To analyze neurite outgrowth in dissociated cell cultures, cells were plated at 10,000 or 50,000 cells/well in defined media with or without neurotrophin. At $36 \mathrm{hr}$ the cultures were fixed in $4 \%$ paraformaldehyde. Using differential interference contrast video microscopy (Leitz objective $100 \times ; 1.2 \mathrm{NA}$ ) and the IMAGE 1 analysis system (Universal Imaging), the lengths of the longest neurite were determined for 25 cells/ coverslip (two or three coverslips per condition). Analysis only included cells that were not in contact with other cells. The proportion of cells with neurites, proportion with neurites $>5 \mu \mathrm{m}$ in length, and the mean neurite length were calculated for each condition. Then the ratio of BDNF treated/control, and NT3 treated/control for each parameter was derived. The corrected proportions of cells with neurites, corrected average length and corrected proportion with neurites $>5 \mu \mathrm{m}$ in length were calculated from four independent experiments. A two sample, twotailed $t$ test was done to analyze statistical significance.

Aggregate cultures. Aggregates of purified granule cells were cultured as described (Gao et al., 1991). Aggregates were allowed to form overnight in dense cultures in 96 well dish, then transferred to polyornithine coated coverslips in a 24 well dish in defined medium as above. The cultures were fixed at the indicated times in $4 \%$ paraformaldehyde in PBS, then processed for immunostaining. For quantitative testing, the coverslips were stained using Q600, a monoclonal antibody to granule cells at 1:50, and a FITC conjugated secondary antibody (Sigma). The cells were viewed with a fluorescence microscope (Leitz $20 \times$ or $40 \times$ objective; $\mathrm{H} 3$ cube). Video images were obtained with a SIT camera (Dage, MTI), and analyzed using the IMAGE 1 system. Statistical significance was analyzed using a Wilcoxon rank-sum test, with a Bonferroni correction (Snedecor and Cochran, 1980).

Northern analysis. RNA was prepared as described (Ausubel et al., 1989). Purified RNA was separated on $1 \%$ agarose gel in formaldehyde, transferred to Genescreen Plus membranes, and hybridized with ${ }^{32} \mathrm{P}$ labeled DNA probes (Bartel et al., 1989). ${ }^{32} \mathrm{P}$-Labeled probes were generated by random priming.

Immunoprecipitation and Western blotting. Protein extracts were prepared from cultured cerebellar cells by lysing the cells in RIPA $(20 \mathrm{~mm}$ Tris, $150 \mathrm{~mm} \mathrm{NaCl}, 10 \%$ glycerol, $1 \%$ NP- $40,1 \%$ deoxycholate, $0.1 \%$ SDS) with $1 \mathrm{~mm}$ vanadate, $1 \mathrm{~mm}$ PMSF, and $10 \mu \mathrm{g} / \mathrm{ml}$ aprotinin for 15 $\min$ at $4^{\circ} \mathrm{C}$. The resultant lysate was cleared by centrifugation. Protein concentration of the supernatant fraction was determined using the Bio$\mathrm{Rad}$ protein assay. The lysates were immunoprecipitated with an antibody to the carboxy-terminal portion of the Trk tyrosine kinase domain

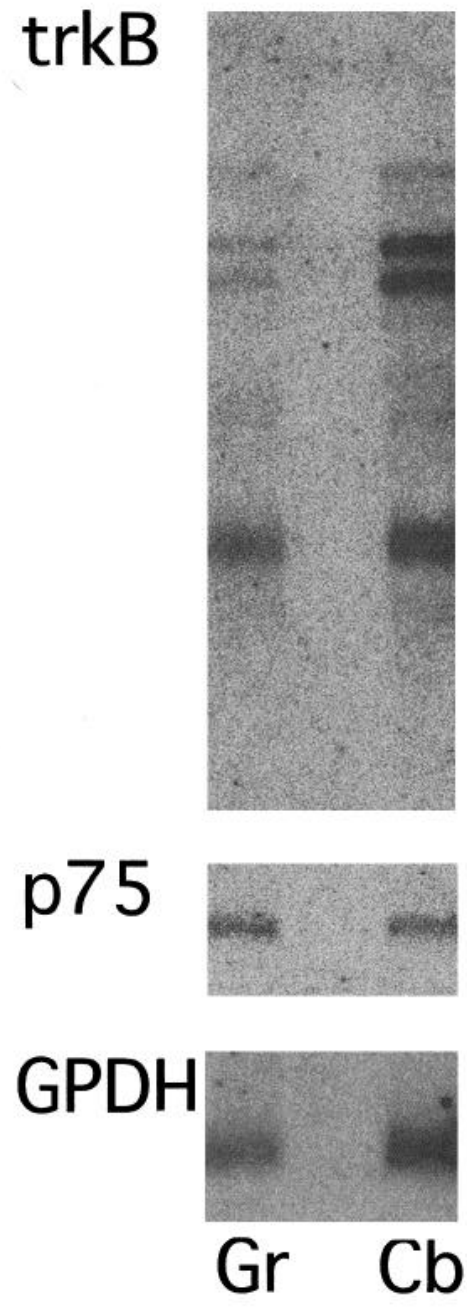

Figure 1. Purified granule cells from $\mathrm{P} 2$ mice express mRNA for the neurotrophin receptors trkB and p75 LANR. RNA was purified from the granule cell fractions of P2 mice, then Northern analysis with sequential hybridizations was done to detect RNA for the neurotrophin receptors. $t r k B$ and LANR messages were detectable in purified granule cells $(\mathrm{Gr})$, and total P2 cerebellum $(\mathrm{Cb})$. The $9 \mathrm{~kb}, 7.5 \mathrm{~kb}, 5 \mathrm{~kb}$, and $2.5 \mathrm{~kb}$ splice variants of $\operatorname{trkB}$ can be seen in the granule cells. GPDH is included as an internal control for loading.

which recognizes TrkA, B, and C (Hempstead et al., 1992) at a dilution of 1:100. The immunoprecipitates were washed three times with RIPA buffer, twice with RIPA $+1 \mathrm{M} \mathrm{NaCl}$, and once with $20 \mathrm{~mm}$ Tris pH 7.4 , and then run on SDS-PAGE. The proteins were transferred to Immobilon, and Western blotting was done as previously described using the anti-Trk antibody at 1:2000, or using the monoclonal anti-phosphotyrosine antibody 4G10 at 1:3000 (Druker et al., 1989).

Reagents. The purified growth factors BDNF and NT3 were a generous gift from Dr. Andrew Welcher of Amgen Inc. NGF was purchased from GIBCO-Bethesda Research Labs. Antibodies were obtained and used as follows: Q600, a monoclonal antibody that recognizes cerebellar granule cells, was a generous gift from R. Hawkes, and was used at 1:50 for immunostaining; antibodies to calbindin, GFAP, MAP-2, acetylated tubulin, and neurofilament heavy chain were obtained from Sigma; taul antibody made by Dr. S. Binder was a gift from Dr. Ken Kosik, Harvard Medical School; sheep antibody to GAP-43 was the gift of Dr. Larry Benowitz, Boston Children's Hospital. Blocking antibody to BDNF was a generous gift from Dr. Josette Carnahan, Amgen Inc. (Ghosh et al., 1994). Antibody to the carboxy-terminal portion of Trk was the generous gift of Dr. David Kaplan, NCI (Hempstead, et al., 1992). The 4G10 monoclonal antibody to phosphotyrosine was obtained from Dr. Tom Roberts, Dana-Farber Cancer Institute (Druker et al., 1989). 


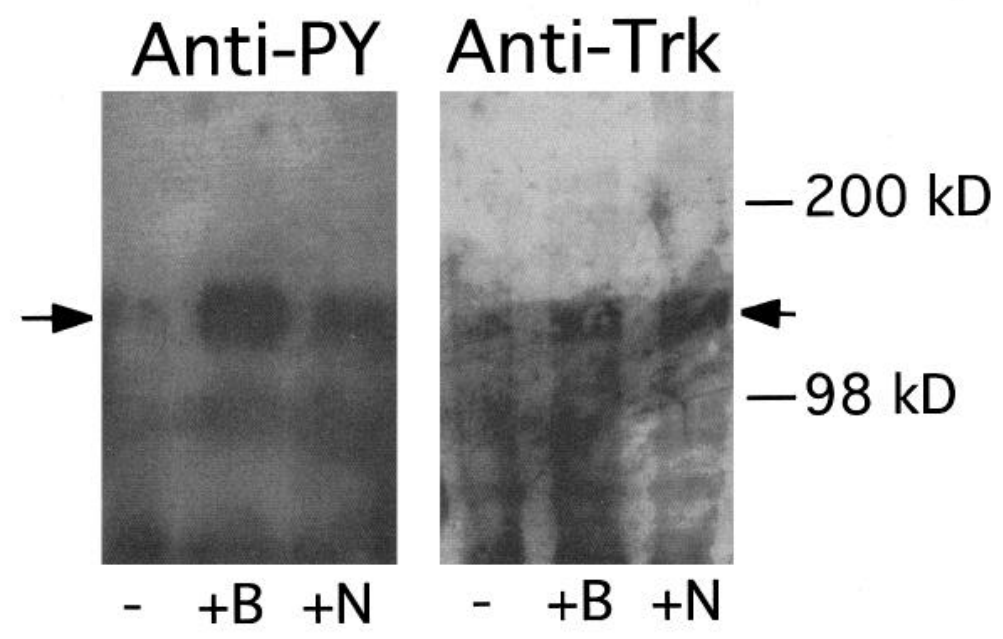

Figure 2. BDNF and NT3 activate Trk receptors in cerebellar granule cells. Purified granule cells from the cerebella of postnatal day 2 Balb/c mice were cultured in serum-free medium for $24 \mathrm{hr}$. Then BDNF $(+B)$ or NT3 $(+N)$ was added to a final concentration of $50 \mathrm{ng} / \mathrm{ml}$; the control was not stimulated (-). The cells were lysed $5 \mathrm{~min}$ after growth factor stimulation, then immunoprecipitated with a pan-Trk antibody. Western analysis of the immunoprecipitates was done using a monoclonal antibody to phosphotyrosine (Anti-Py), and the anti-Trk antibody (Anti-Trk). BDNF induced the tyrosine phosphorylation of a Trk molecule, presumably gp145-TrkB. NT3 also induced Trk tyrosine phosphorylation, although to a lesser extent. The NT3-activated Trk is assumed to be gp150-TrkC. Densitometric analysis of the blots indicate that BDNF stimulates Trk tyrosine phosphorylation 5.5-fold compared with control, while NT3 stimulates Trk phosphorylation 2.3-fold.

Clones for $\operatorname{trkB}$ and $\operatorname{trk} C$ were obtained from Dr. Mariano Barbacid, Squibb. The clone for p75 was from Dr. Moses Chao, Cornell University Medical College, glyceraldehyde phosphate dehydrogenase (GPDH) was obtained from Dr. Michael Greenberg, Harvard Medical School. The GAP-43 clone was the gift of Dr. Nina Irwin, Boston Children's Hospital.

\section{Results}

Functional TrkB and TrkC are present in purified granule cells

In vitro studies of developing granule cells have been facilitated by the possibility of isolating granule cells. Established protocols yield granule cell preparations that are 95-99\% pure (Hatten, 1985; Gao et al., 1991). When prepared from neonatal mouse cerebellum, these cell fractions contain cells from both the EGL and the IGL. As shown in Figure 1, RNA for the neurotrophin receptors: $\operatorname{trk} B$, and the low affinity receptor are detectable in P2 granule cells using Northern analysis (Fig. 1). Consistent with in situ hybridization studies (Tessarollo et al., 1993), a faint trkC signal was detected in the granule cell RNA (data not shown)

To determine whether the receptor mRNAs are translated into functional proteins, we analyzed Trk phosphorylation in response to neurotrophins. For each Trk, binding of its neurotrophin ligand induces tyrosine phosphorylation. A Trk protein was tyrosine phosphorylated following BDNF treatment of purified $\mathrm{P} 2$ granule cells, indicating the presence of the BDNF receptor, TrkB (Fig. 2). NT3, the TrkC ligand, also induced tyrosine phosphorylation of a Trk receptor in these cells, suggesting that functional TrkC receptors are present (Fig. 2). Thus early granule cells express two functional Trk receptors, TrkB and TrkC.

\section{A developmental switch in functional Trk receptors during cerebellar development}

The Trk B and Trk C genes each encode multiple species of mRNA through alternative splicing mechanisms, and some of the splice variant transcripts omit the cytoplasmic tyrosine kinase domain (Klein et al., 1990; Middlemas et al., 1991; Lamballe et al., 1993; Valenzuela et al., 1993). We analyzed the levels of total receptor mRNA and kinase-positive receptor mRNA in the cerebella of mice at 1 week intervals beginning at birth. As shown in Figure 3, the total level of trkB mRNA in the developing cerebellum decreased only slightly in the first week of life. However the level of the 9.0 and $5.5 \mathrm{kB}$ mRNA transcripts which encode the tyrosine kinase-positive protein (Klein et al., 1990; Middlemas et al., 1991), decreased steadily over this time period. In contrast, as shown in Figure 3, expression of all forms of $t r k C$ increased steadily over the first 3 weeks of life, and then remained at high levels into adulthood. Taken together, these changes result in a reversal of the ratio between the tyrosine kinase encoding forms of $t r k B$ and $t r k C$ during cerebellar development. The ratio of $\operatorname{trkB} / \mathrm{trkC}$ transcripts encoding functional receptor falls from 5:1 in neonatal animals to $1: 1$ at 3 weeks when the external germinal layer has almost disappeared, and 1:3 in adults.

In identical samples, we monitored expression of $\mathrm{p} 75$, the low affinity neurotrophin receptor. As shown in Figure 3, p75 mRNA is high in neonatal and 1 week old mice, and then decreases 250 -fold. This pattern of mRNA expression is consistent with previous studies on p75 expression in developing cerebellum (Fig. 1 and Schatteman et al., 1988; Yan and Johnson, 1988; Friedman et al., 1991).

Figure 3. Changes in expression of neurotrophin receptors during cerebellar development. RNA was prepared from the cerebella of Balb/c mice at postnatal day 0,1 week, 2 weeks, 3 weeks, and adult mice. Northern analysis was done sequentially for $\operatorname{trkB}$, $\operatorname{trk} C$, and the low affinity neurotrophin receptor, p75. The $9 \mathrm{~kb}$ and the $5.5 \mathrm{~kb}$ bands that encode the full length $t r k B$ receptor tyrosine kinase, and the $14 \mathrm{~kb}$ band that encodes the full length $t r k C$ receptor tyrosine kinase are indicated with arrows. The $7.5 \mathrm{~kb}$ truncated trkB is indicated with an arrowhead. The smaller mRNA species are the same size as previously described alternative splice forms (Klein et al., 1990). The blots were then stripped and reprobed with glyceraldehyde phosphate dehydrogenase $(G P D H)$, to control for unequal loading. The densities of the signals were calculated using the Phosphorimager. $B$ shows the quantitative analysis of these data. The ratios between the full length $\operatorname{trk} B$ transcripts $(9$ and $5.5 \mathrm{~kb})$ and the full 
A. Age in weeks $0 \begin{array}{llll}0 & 1 & 3 & 20\end{array}$

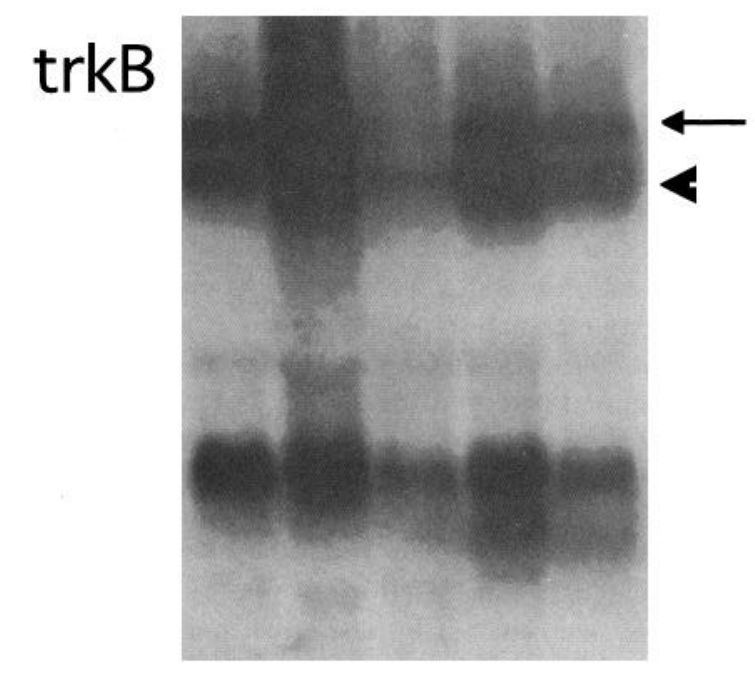

\section{trkC}
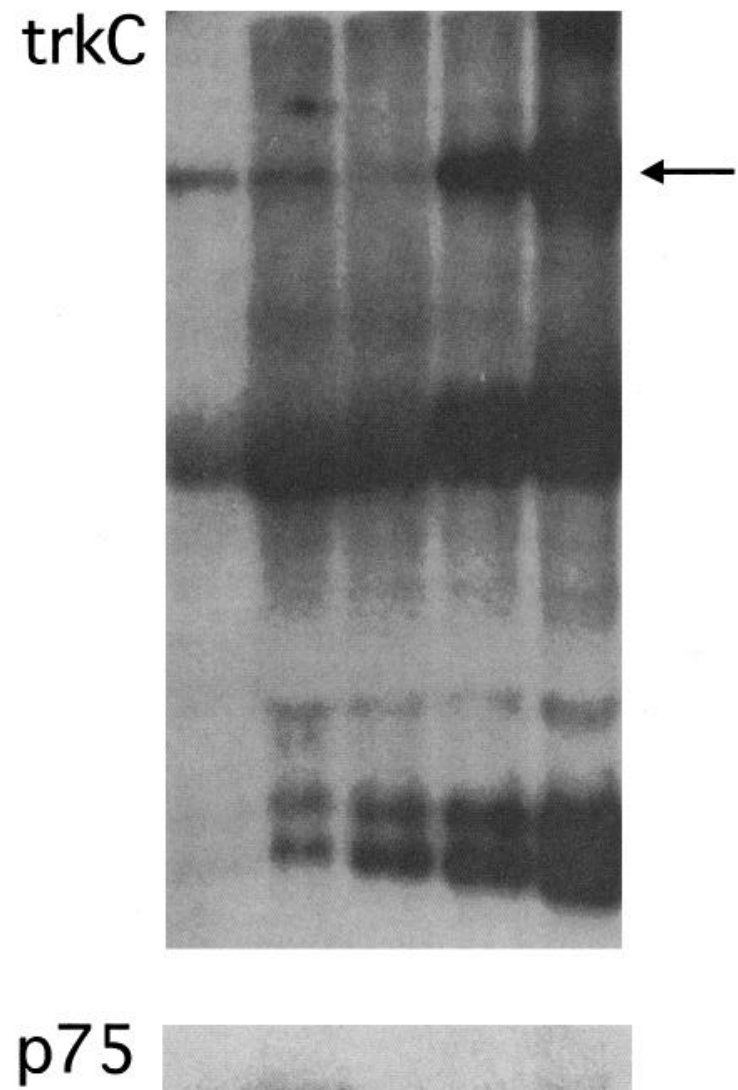

GPDH
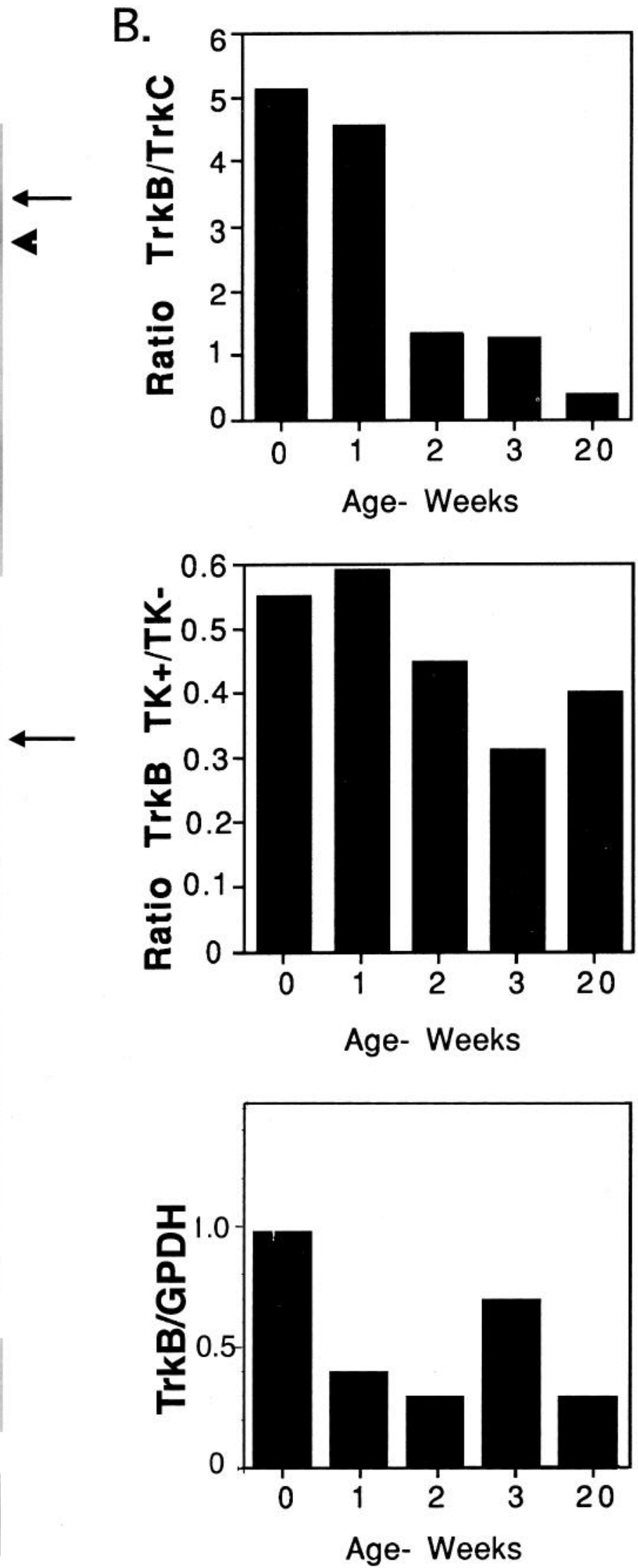

length $14 \mathrm{~kb} t r k C$ are shown in the upper graph. Quantitative analysis of the ratios between the full length forms that encode tyrosine kinasepositive TrkB ( 9 and $5.5 \mathrm{~kb}$ ) and the $7.5 \mathrm{~kb}$ truncated form of $t r k B$ is shown in the middle graph. The relative level of total $t r k B$ mRNA is shown in the lower graph. 
Table 1. Neurite outgrowth in dissociated cell culture

\begin{tabular}{llll} 
& $\begin{array}{l}\text { Cells with } \\
\text { neurites }\end{array}$ & $\begin{array}{l}\text { Average } \\
\text { length }(\mu \mathrm{m})\end{array}$ & Neurites $>5 \mu \mathrm{m}$ \\
\hline BDNV/cont & $1.19 \pm 0.10$ & $1.28 \pm 0.21$ & $1.51 \pm 0.20^{*}$ \\
NT3/cont & $1.00 \pm 0.15$ & $1.01 \pm 0.29$ & $0.96 \pm 0.13$ \\
\hline$* p<0.05$ & & &
\end{tabular}

$* p<0.05$.

\section{BDNF enhances neurite outgrowth}

Although the receptors for the neurotrophins BDNF and NT3 are closely related transmembrane tyrosine protein kinases, the anatomical segregation of the receptors in developing cerebellum suggests that they might regulate separate functions. We initially used dissociated cultures of purified granule cells to test the effects of neurotrophins on neurite growth. As shown in Table 1, when the results from four separate experiments were analyzed together, BDNF increased the proportion of cells with neurites $>5 \mu \mathrm{m}$ to $150 \%$ of control $( \pm 20 \%, P<0.05)$. No significant differences were seen in the proportion of cells with neurites, or the average length of the neurites in cultures grown in BDNF. In contrast, NT3 did not affect outgrowth as assessed by any of these measurements. Neither BDNF nor NT3 caused any detectable difference in neurite branching observed in response to the neurotrophins.

We then turned to an aggregate culture system devised by Gao et al. (1991) to analyze further the effects of the BDNF and NT3 on axonal outgrowth. In these reaggregated cell cultures, there is less cell death and more cell proliferation than in dissociated cell cultures. Furthermore, the neurites elongate rapidly in this system, and so effects of the neurotrophins can be studied in short term cultures. Consistent with the results using dissociated granule cell cultures, BDNF increased neurite outgrowth in aggregated P2 granule cells (Fig. 4). The effect of BDNF on outgrowth in these short term cultures is not due to a change in cell survival, as assessed by propidium iodide staining (data not shown). Neurite outgrowth was analyzed quantitatively (Gao et al., 1992; Zou et al., 1993) and these data are summarized in Table 2. BDNF, but not NT3 or NGF, enhanced neurite outgrowth as assessed by (1) the average radius of the halo of processes that protrudes from the aggregate, (2) the length of the longest process, and (3) the mathematical area of the processes. The differential response to BDNF and NT3 was statistically significant using any of the three parameters. For convenience, we tabulated radial measurements for the rest of the analysis. Dose-response studies shown in Figure $5 B$, indicate that BDNF enhanced neurite outgrowth at concentrations that are likely to be found in vivo. The half-maximal response to BDNF was observed at $1 \mathrm{ng} / \mathrm{ml}$.

Time course analyses of the effects of BDNF and NT3 at 10 $\mathrm{ng} / \mathrm{ml}$ are shown in Figure $5 A$. There was little or no effect of BDNF on neurite outgrowth before $24 \mathrm{hr}$; the effects were most dramatic at $36 \mathrm{hr}$ in culture. In this experiment neurite outgrowth was analyzed at $12 \mathrm{hr}$ intervals; in another experiment where time points were taken at $6 \mathrm{hr}$ intervals no significant effect was seen prior to $24 \mathrm{hr}$ of exposure to the neurotrophin. This time course suggests that BDNF does not stimulate the initial outgrowth of neurites, but instead either enhances neurite elongation, or stabilizes growing neurites.

As illustrated in Figure 4, BDNF not only increased the extent of outgrowth, but also influenced the appearance of the granule cell neurites. In aggregates exposed to BDNF the processes appear finer, and less compacted. This morphology suggests that BDNF enhances outgrowth of unfasciculated processes.

\section{Endogenous BDNF contributes to neurite outgrowth}

In these studies, BDNF consistently increased neurite outgrowth. However, there was some variability from one aggregate cell culture to the next. This variability was a function of background outgrowth. Cultures which showed higher levels of background or constitutive outgrowth responded less well to the addition of exogenous BDNF. It occurred to us that the background outgrowth of these aggregate cell cultures might reflect the activity of endogenous BDNF (Hofer et al., 1990). Therefore, we ana-
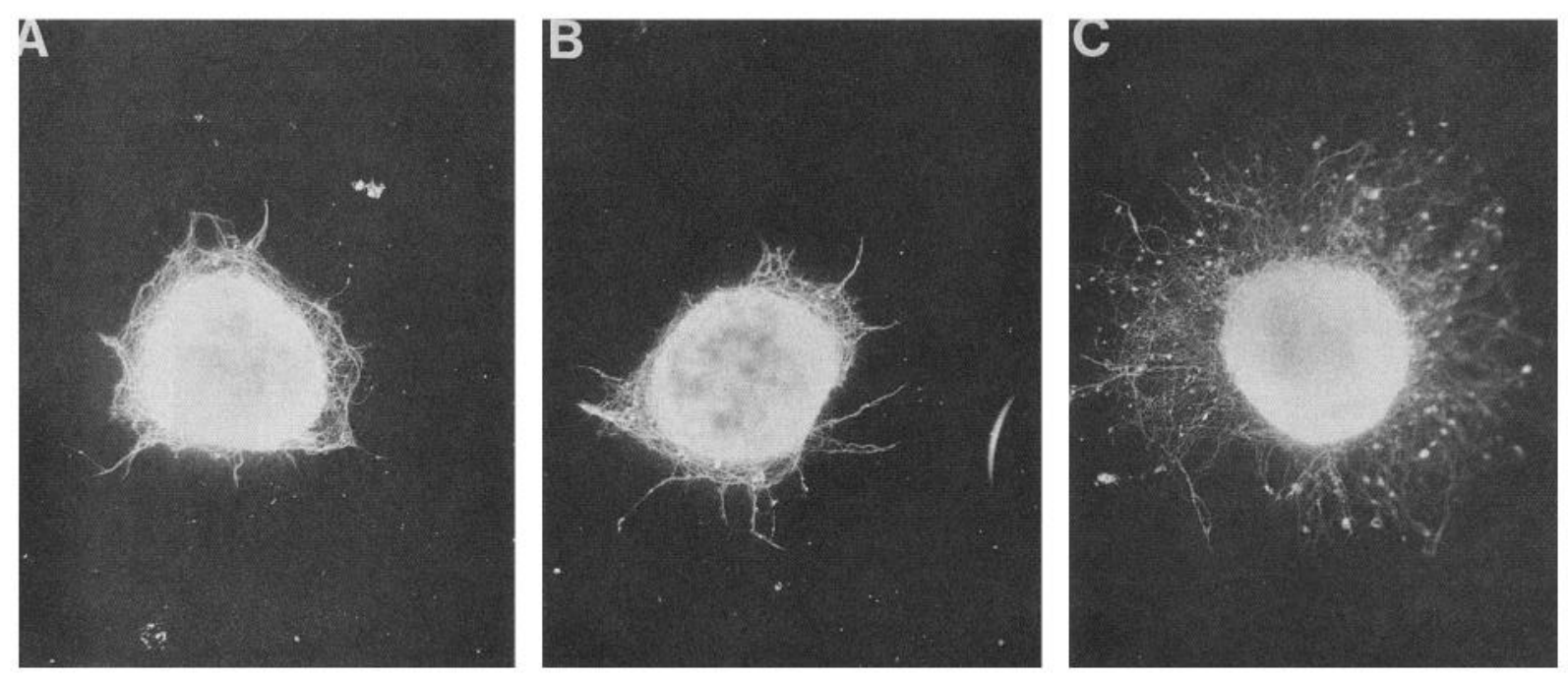

Figure 4. BDNF, but not NT3, increases the growth of neurites from early granule cells. Cerebellar granule cells were isolated from postnatal day $2 \mathrm{Balb} / \mathrm{c}$ mice. The granule cells were plated at high density in DME $+10 \%$ FBS overnight, to allow aggregates to form. The aggregates were transferred to polyornithine coated coverslips in serum free medium with no added growth factor $(A)$, with $10 \mathrm{ng} / \mathrm{ml} \mathrm{NT3}(B)$, or with $10 \mathrm{ng} / \mathrm{ml}$ BDNF $(C)$. After $36 \mathrm{hr}$ in culture, the aggregates were fixed, and stained with the monoclonal antibody Q600, an antibody specific for granule cells. As shown here, BDNF, and not NT3, significantly increased the radial outgrowth of neurites. 
Table 2. Quantitative analysis of neurite outgrowth

\begin{tabular}{lcrrr} 
& \multicolumn{1}{c}{ Control } & BDNF & \multicolumn{1}{c}{ NGF } & \multicolumn{1}{c}{ NT3 } \\
\hline Radius $(\mu \mathrm{m})$ & $30.7 \pm 1.72$ & $52.2 \pm 3.3^{*}$ & $33.2 \pm 1.6$ & $35.4 \pm 2.2$ \\
Longest process $(\mu \mathrm{m})$ & $64.7 \pm 2.6$ & $97.9 \pm 8.5^{*}$ & $71.9 \pm 5.1$ & $78.2 \pm 7.1$ \\
Area $\left(\mu \mathrm{m}^{2}\right)$ & $10,877 \pm 990$ & $25,466 \pm 2735^{*}$ & $11,212 \pm 831$ & $12,872 \pm 724$ \\
\hline
\end{tabular}

Growth factors were applied at a concentration of $20 \mathrm{ng} / \mathrm{ml}$.

$* p<0.05$.

lyzed granule cell outgrowth in the presence of K252a, which specifically inhibits Trk tyrosine kinase activity when used at low concentrations (Koizumi et al., 1988; Tapley et al., 1992). At concentrations of $200 \mathrm{nM}, \mathrm{K} 252 \mathrm{a}$ slightly decreased the constitutive outgrowth of the granule cells (Fig. 5C), and eliminated the response to exogenous BDNF. Blocking antibodies provide a more selective way of inhibiting the effects of endogenous BDNF. A specific, blocking antibody to BDNF (the kind gift of Dr. J. Carnahan, Amgen) has been prepared and characterized (Ghosh et al., 1994). 'I'he quantitative analysis of neurite outgrowth in the presence of blocking antibodies is shown in Figure $5 C$; the blocking antibody to BDNF tended to decrease neurite outgrowth. Furthermore, as shown in Figure 6 aggregates cultured in the presence of the blocking antibody to BDNF had a distinctive morphology. Instead of a large outward directed halo of fine neurites, the aggregate was surrounded by a smaller, very tight bundle of processes. Nonimmune turkey serum and an antibody to NT3 prepared in a similar fashion and used at comparable concentration, did not show this effect. Taken together, these data indicate that endogenous BDNF contributes to the constitutive outgrowth of aggregate cell cultures and that exogenous BDNF enhances this growth. These data also suggest that BDNF influences the morphology, as well as the extent of outgrowth.

\section{BDNF enhanced neurites are axons}

To determine the nature of the neurites whose growth is enhanced by BDNF, we used a panel of specific antibodies to investigate the nature of the processes formed by granule cell aggregates. As shown in Figure 7, the processes stain well with several antibodies that preferentially recognize the cytoskeletal elements of axons (reviewed in Matus, 1988). Consistent with previous studies (Baptista et al., 1994), antibodies to the heavy chain of neurofilament (Hirokawa et al., 1984) stained these proccsscs. Antibodies that recognize other axonal cytoskeleton components, acetylated tubulin (Chitnis and Kuwada, 1990), and the microtubule associated protein tau (Kosik and Finch, 1987) also recognized the granule cell neurites. In contrast, antibodies to MAP2, which is preferentially found in dendrites and the cell body (Caceres et al., 1984; Kosik and Finch, 1987), were ineffective in staining most of the processes. Furthermore, antibodies to the growth associated protein GAP43, which is more highly expressed in growing axons than dendrites (Goslin et al., 1988) also stained the neurites. Neither BDNF nor NT3 altered the antigenic characteristics of the granule cells processes. Thus BDNF enhances the growth of processes that were already destined to be axons.

\section{$B D N F$ increases expression of GAP-43}

To determine molecular correlates for the effects of BDNF on neurite outgrowth, we analyzed the expression of GAP-43 mRNA expression in control and in neurotrophin treated P2 cer- ebellar cultures. GAP-43 is present in axonal growth cones, and its expression is increased during neurite elongation (Levin and Dunn-Meynell, 1993). As illustrated in Figure 8, BDNF and NT4/5, but not NGF or NT3, increased the expression of GAP43 compared with control cultures. Quantitative analysis of these data indicate that the relative expression of GAP-43 was increased by $50-100 \%$ after $2 \mathrm{~d}$ in vitro in the presence of BDNF or NT4/5. This observation supports the conclusion that BDNF enhances axonal elongation.

\section{NT3 affects the pattern of neurite outgrowth}

In the course of conducting dose/response measurements with BDNF and NT3, we noticed a subtle but reproducible effect of NT3 on the pattern of neurite outgrowth. Intermediate $(10 \mathrm{ng} /$ $\mathrm{ml}$ ) doses of NT3 resulted in a more dense pattern of neurites within the halo. Quantitative analysis of the outgrowth in aggregates grown in NT3 at $10 \mathrm{mg} / \mathrm{ml}$ showed a sinall decrease in outgrowth (Fig. $5 B$ ).

To investigate further this effect, we examined the morphology of cultures grown in the presence of BDNF or NT3 and stained with antibodies that preferentially recognize the growing axonal processes. When visualized with antibodies to GAP-43, BDNF and NT3 each have distinct effects on the morphology of the neurites. As shown in Figure 9, BDNF increases the extent of outgrowth, and also results in individual processes growing radially. The growth cones appear thicker in the presence of BDNF. In contrast, NT3 caused a small reduction in the radius of outgrowth, and the fibers within the halo appear more densely packed. Similar results were seen when aggregates were stained with antibodies to Q600 (Fig. 4), or with antibodies to the neurofilament heavy chain (data not shown). The patterns of outgrowth seen are consistent with BDNF increasing elongation of individual neurites, and NT3 increasing fasciculation or branching.

\section{Discussion}

These studies demonstrate that the ratio between the $\operatorname{trk} B$ and trk $C$ receptor tyrosine kinases reverses as granule cells differentiate. Moreover, the data indicate that cellular responses to the activation of TrkB and TrkC are not equivalent. Activation of TrkB by its ligand leads to enhanced axonal outgrowth whereas activation of TrkC by its ligand may affect the pattern of outgrowth, perhaps by influencing fasciculation. In the external germinal cell layer, there is a plausible consequence of the developmentally regulated switch in Trk receptors. Neurites extended by granule cells may initially grow longer in response to BDNF. As cells migrate from the external germinal layer, neurites may fasciculate as the predominant neurotrophin receptor switches from TrkB to TrkC.

\section{Regulation of neurotrophin receptor expression}

Developmentally regulated switches in neurotrophin sensitivity similar to the one noted here have been described in both pe- 

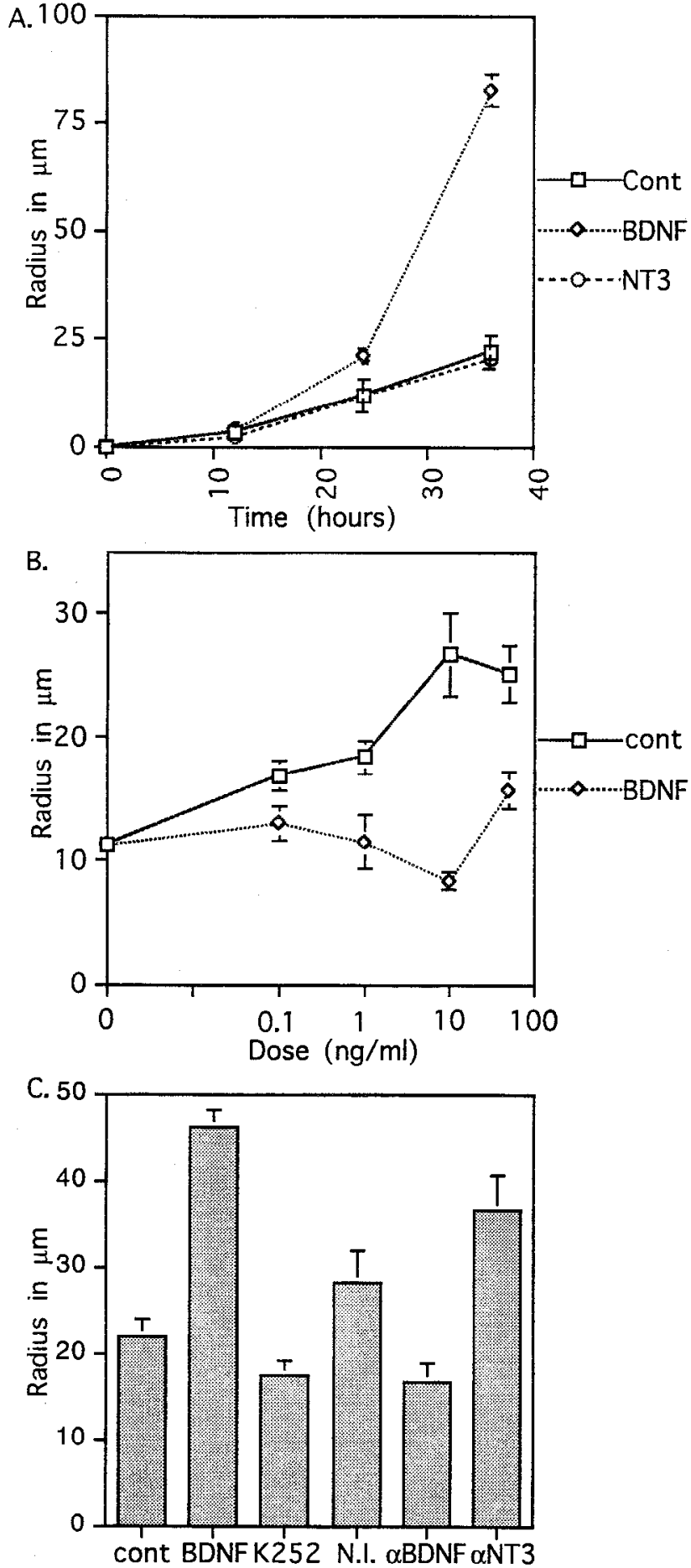

Figure 5. Quantitative analysis of the effects of BDNF and NT3 on neurite outgrowth. A, Time course of the effects of BDNF and NT3 on neurite outgrowth. Granule cell aggregates were prepared, then cultured in serum free medium alone (control), or with added BDNF $(10 \mathrm{ng} / \mathrm{ml})$ or NT3 $(10 \mathrm{ng} / \mathrm{ml})$. Aggregates were fixed at 12,24 , or $36 \mathrm{hr}$, and then stained with the antibody Q600. The radius of the halo of ncurite outgrowth was analyzed for each aggregate (8-25 aggregates per condition). $B$, Dose-response curves of the effects of the neurotrophins BDNF and NT3 on neurite outgrowth at $24 \mathrm{hr}$. Granule cell aggregates were prepared and cultured in serum free medium (control), or supplemented with BDNF and NT3 at the indicated concentrations. After 24 $\mathrm{hr}$ the aggregates were fixed and stained with the antibody Q600. The radius of the halo of neurite outgrowth was measured for each aggregate. BDNF greatly enhanced neurite outgrowth of the cerebellar granule cells while NT3 had a slight inhibitory effect. $C$, Endogenous out- ripheral and central neurons. Early trigeminal ganglia neurons show enhanced survival in response to $\mathrm{BDNF}$, while their more mature counterparts require NGF for survival (Buchman and Davics, 1993). This reflects changes in receptor cxpression: levels of $\operatorname{trk} A$, and of the p75 low affinity receptor increase at the time the cells are becoming dependent on NGF for survival (Wyatt and Davies, 1993). Similarly, developing sympathetic neurons initially respond to NT3 and only later respond to NGF. Birren et al. have shown that the developing sympathetic neurons undergo a switch, first expressing the NT3 receptor TrkC, and later expressing the NGF receptor TrkA. Notably, there appears to be a time when the developing neurons express both TrkA and TrkC (Birren et al., 1993). In sympathetic neurons, the neurotrophins themselves orchestrate the switch in receptor expression (Verdi and Anderson, 1994).

In the cerebellum, an increase in $t r k C$ expression is the primary factor leading to a switch in the ratio between the two receptors. An alteration in the splice pattern of $\operatorname{trk} B$, with a relative increase in the expression of mRNA encoding the tyrosine kinase negative form of $\operatorname{TrkB}$, also contributes to the molecular basis of the developmental change in responsiveness (Fig. 3).

In addition to a developmental change in Trk receptor expression, granule cells also undergo a very dramatic developmentally regulated suppression of p75 gene expression, with levels of mRNA decreasing 250-fold. Peak levels of p75 expression coincide with the period of extensive granule cell death (Wood et al., 1993). In tissue culture model systems, p75 expression facilitates programmed cell death (Rabizadeh et al., 1993). Since $\mathrm{BDNF}$ is a survival factor for early granule cells in vitro (Segal et al., 1992; Lindholm et al., 1993), BDNF may prevent p75 mediated apoptosis in premigratory granule cells. Another possibility is that p75 may increase the sensitivity of early granule cells to neurotrophin, as has been demonstrated in other systems (Barker and Shooter, 1994; Hantzopoulos et al., 1994; Verdi et al., 1994). This may be particularly critical since the level of BDNF in the cerebellum is low early in life (Maisonpierre et al., 1990).

\section{Axonal outgrowth}

We and others have shown that BDNF enhances granule cell neurite outgrowth (Segal et al., 1992; Lindholm et al., 1993). Data presented here address the mechanistic basis of this outgrowth. Our time course studies (Fig. 5) and observations on dissociated cell cultures (Table 1) suggest that BDNF does not actually initiate neurite outgrowth. Expression analysis of axonal and dendritic markers show that BDNF does not alter the nature of the processes (Fig. 7). By default, BDNF must enhance elongation, perhaps by stabilizing early processes. In support of this hypothesis, we have found that BDNF and NT4/5 both result in

$\leftarrow$

growth of aggregate cultures is decreased when BDNF function is blocked. Granule cell aggregates were grown in serum-free medium

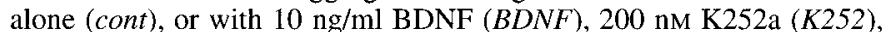
nonimmune turkey serum at 1:500 (N.I.), a blocking antibody to BDNF at 1:500 $(\alpha B D N F)$, or a blocking antibody to NT3 $(\alpha N T 3)$. After $36 \mathrm{hr}$, cultures were fixed, stained with Q600, and analyzed. As above BDNF significantly increased neurite outgrowth. Aggregates grown in K252a show a reduction of endogenous and BDNF-stimulated outgrowth. Outgrowth was decreased somewhat by a blocking antibody to BDNF when compared to nonimmune serum, although this trend was not statistically significant. 

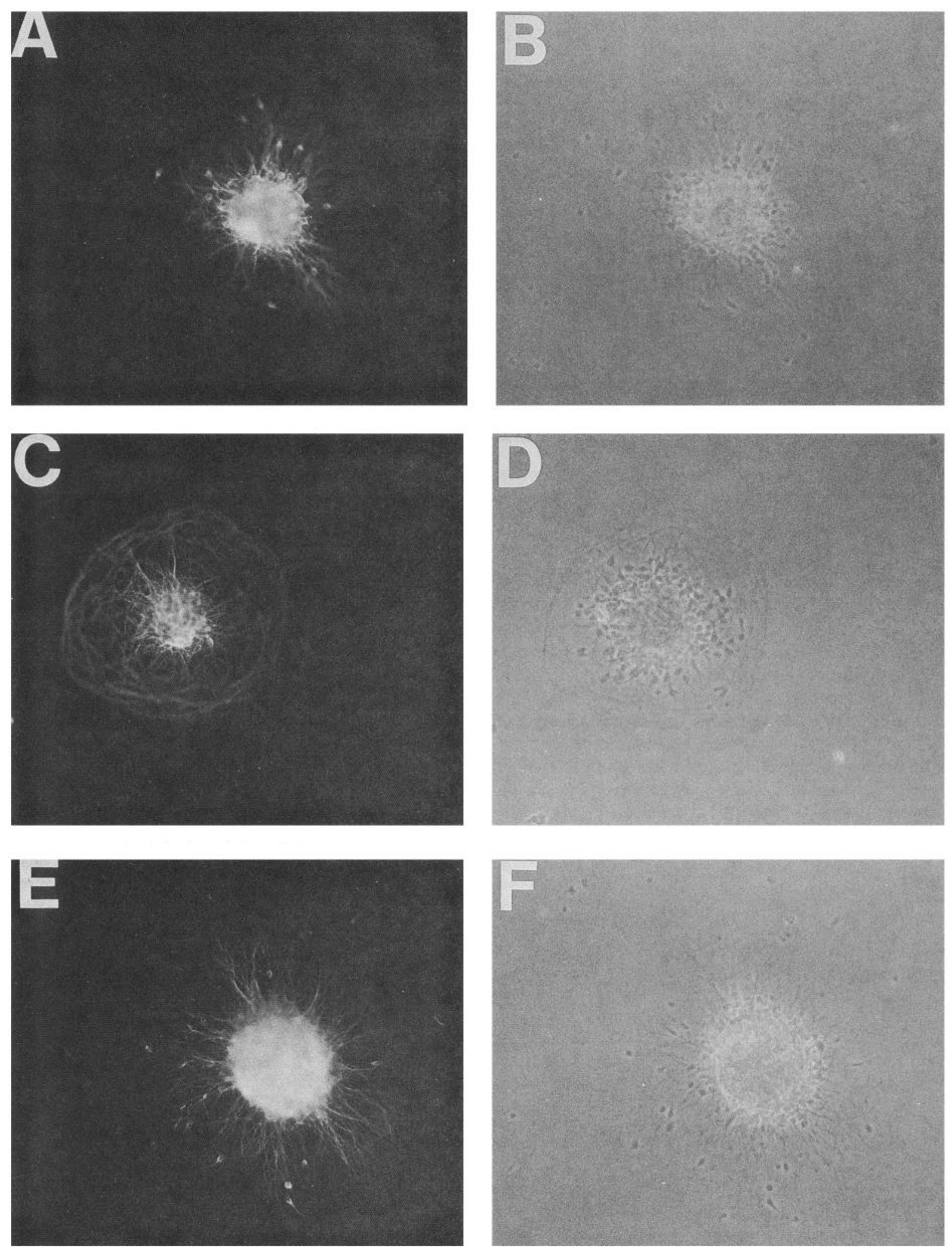

Figure 6. A blocking antibody to BDNF alters endogenous neurite outgrowth. Granule cell aggregates from P4 mice were cultured for 36 hr in serum free medium $(A, B)$ with anti-BDNF at 1:500 dilution $(C, D)$, or with $10 \mathrm{ng} / \mathrm{ml}$ BDNF $(E, F)$. Fixed cultures were stained with the Q600 antibody. $A, C$, and $E$ show fluorescent images; $B, D$, and $F$ show the corresponding phase images. In the presence of a blocking antibody to BDNF, the halo of neurites is denser and smaller. This effect was seen in 15 of 16 aggregates analyzed. 

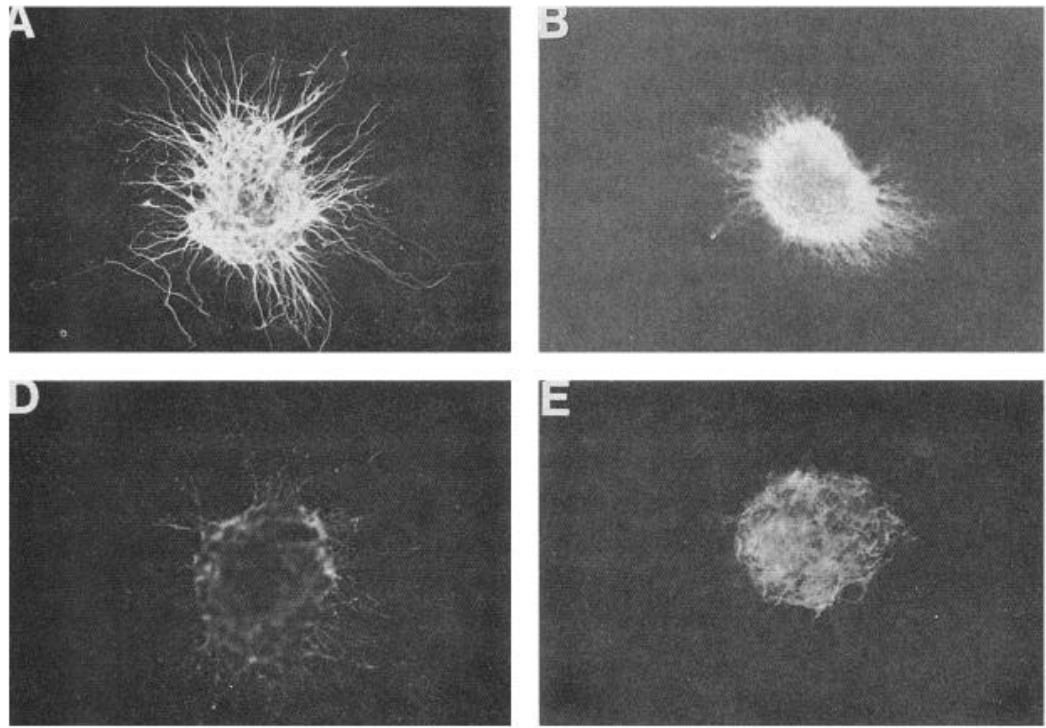
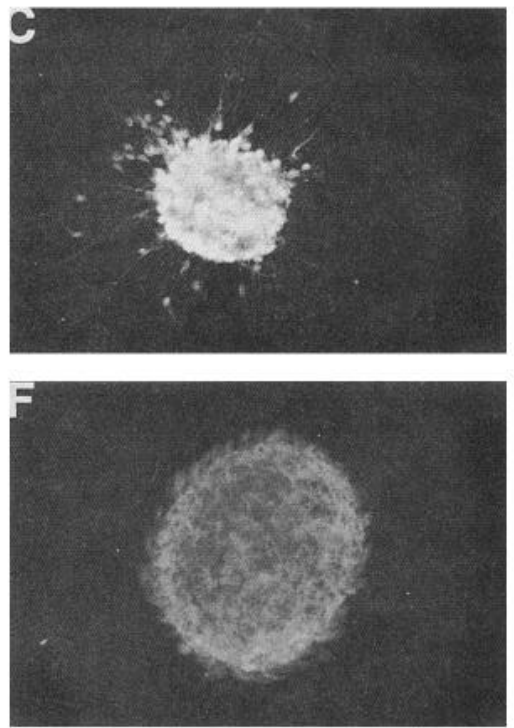

Figure 7. BDNF-stimulated neurites are axons. Aggregate cultures from $\mathrm{P} 4 \mathrm{mice}$ were cultured for $36 \mathrm{hr}$ in serum free medium with $10 \mathrm{ng} / \mathrm{ml}$, and then fixed and stained with an antibody to, in $A$, acetylated tubulin $(1: 1000) ; B$, tau $1(1: 500) ; C$, neurofilament heavy chain subunit (1:100); $D$, GAP-43 (1:100); $E$, MAP2 (1:250); $F$, control-no primary antibody. The neurites are stained by all the antibodies that preferentially recognize axons $(A-D)$ but not MAP2, a dendritic marker $(E)$. The same pattern of staining was seen in control cultures (no neurotrophin) and NT3-treated cultures.

an increase in the level of GAP-43 mRNA within $48 \mathrm{hr}$ (Fig. 8).

Our data also indicate that activation of Trk B by BDNF is not the sole determinant of neurite outgrowth in the developing cerebellum. We observed a small reduction in neurite outgrowth in the presence of antibodies to BDNF and in the presence of K252a (Fig. 5C). These observations are consistent with the phenotype of mice with null mutations of BDNF. In BDNF -/ - homozygotes, granule cell maturation is delayed but not ultimately prevented (Jones et al., 1994).

\section{Cont NGF BDNF NT3 NT4}

\section{GAP-43}

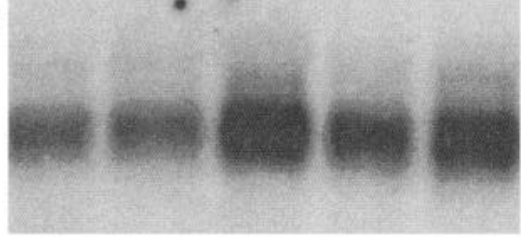

\section{GPDH}

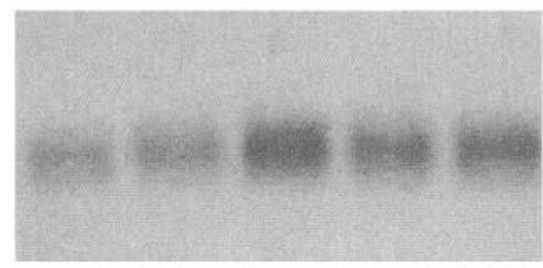

Figure 8. BDNF increases expression of the growth associated molecule GAP-43. P2 cerebellar cells were grown in dissociated cultures in N2 medium alone (control), or supplemented with the indicated neurotrophin at $10 \mathrm{ng} / \mathrm{ml}$. After $2 \mathrm{~d}$ in vitro, RNA was isolated, and analyzed on a $1 \%$ agarose gel. Northern analysis was done with GAP-43; the blot was then stripped and reprobed with GAPDH as an internal control for loading. The results were quantitated using the Phosphorimager. GAP-43 was $150 \%$ of control in cultures treated with BDNF or NT4/5, but were $90-110 \%$ or control in cultures treated with NGF or NT3.
The studies described here were all carried out in serum free medium, on synthetic polyornithine substrate. The substrate, as well as soluble factors are important determinants of neurite outgrowth. Substrate composition can influence fasciculation and the extent of outgrowth (Lemmon et al., 1992). The extent to which neurotrophins affect granule cell neurite outgrowth may depend on the substrate. For example, cerebellar granule cells with targeted gene deletions in $s r c$ have impaired neurite outgrowth on a substrate of $\mathrm{Ll}$, but not on a laminin substrate (Ignelzi et al., 1994).

The molecular mechanism by which BDNF enhances outgrowth remains to be defined. Effects on gene expression, such as the increase in GAP-43 (Fig. 8) are one aspect of this process. The neurotrophins may also alter membrane composition, or cause posttranslational protein modification. Members of the immunoglobulin superfamily, and components of the extracellular matrix, are potential targets for the neurotrophin effects, as these molecules influence granule cell outgrowth and fasciculation (Furley et al., 1990; Lochter and Schachner, 1993; Williams et al., 1994).

\section{Effects of BDNF and NT3 on the pattern of neurite outgrowth}

BDNF increased the extent of outgrowth in dissociated cells and in aggregate cultures as measured quantitatively, but also influenced the appearance of the granule cell processes. Aggregates grown in the presence of BDNF gave rise to finer, less compact neurites. In contrast, NT3 had no effect on neurite growth in the dissociated cells, and only slightly diminished outgrowth in aggregate cultures. However, aggregates grown in NT3 exhibited a more compacted appearance than the control or BDNF-treated cultures (Fig. 9). These effects of BDNF and NT3 could reflect changes in fasciculation or branching, with BDNF enhancing growth of unbranched, or unfasciculated processes. In contrast, NT3 may enhance fasciculation or branching. Our data suggest that the molecular mechanisms whereby these two neurotrophins 

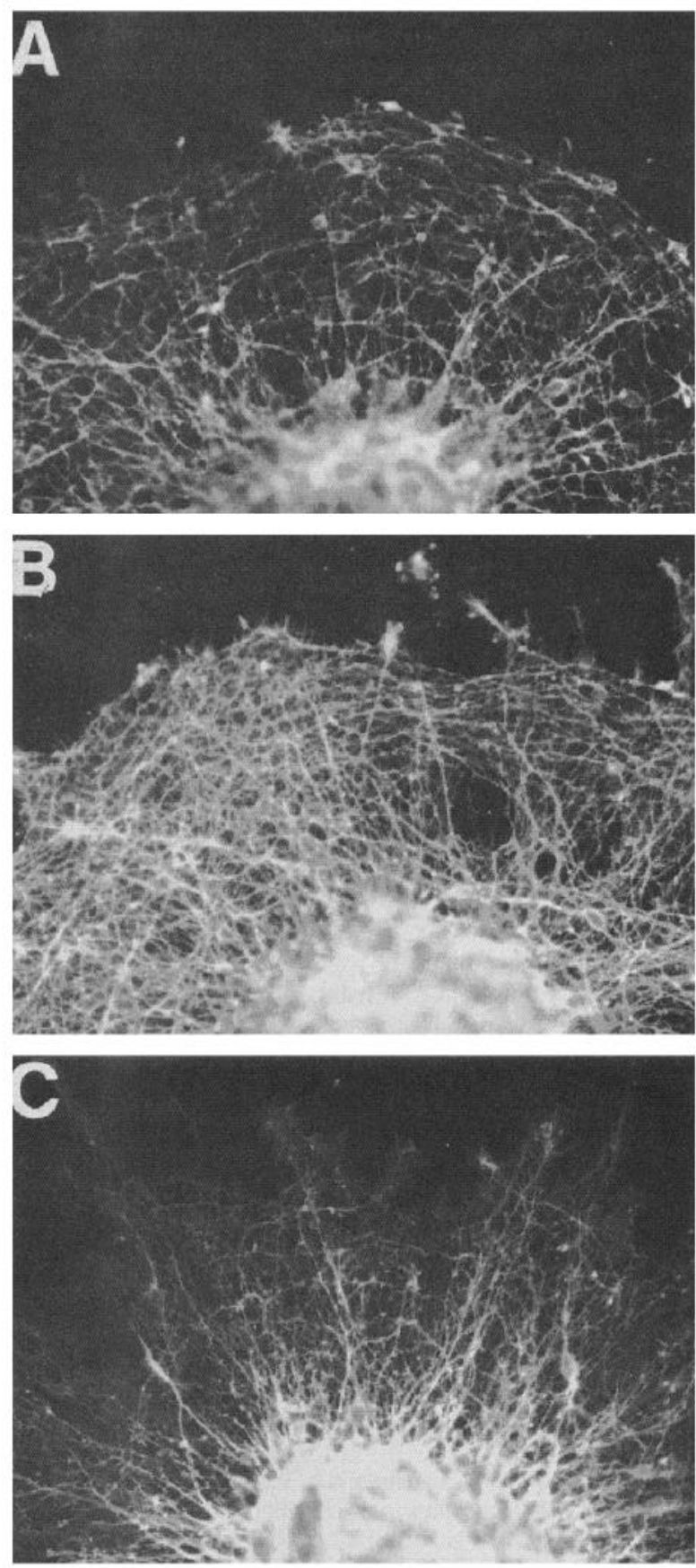

Figure 9. BDNF and NT3 have distinct effects on the morphology of neurite outgrowth. Cerebellar granule cells were purified from P2 mice and cultured as aggregates in defined medium alone $(A)$, supplemented with $10 \mathrm{ng} / \mathrm{ml} \mathrm{NT} 3(B)$, or with $10 \mathrm{ng} / \mathrm{ml}$ BDNF $(C)$. After $24 \mathrm{hr}$, the cultures were fixed, and stained with an antibody to GAP-43 (the gift of Dr. L. Benowitz). In the presence of NT3, the halo of neurites is more dense, suggesting that NT3 may enhance fasciculation or branching. In contrast, in the presence of BDNF, the neurites are finer, and end in broad growth cones. This is consistent with BDNF enhancing the elongation of unfasciculated processes.

influence neurite morphology are distinct; BDNF enhances GAP43 related growth cone elongation, while NT3 does not.

The distinct effects seen with BDNF and NT3 suggest that BDNF acts via TrkB, while NT3 acts via its own specific receptor, TrkC. In accord with the findings of (Tessarollo et al.,
1993), data shown here (Fig. 2) indicate that both TrkB and TrkC are synthesized in granule cells in neonatal cerebellum. We cannot however, exclude the possibility that the morphologic effects seen with NT3 reflect an antagonist effect of NT3 at the TrkB receptor. Aggregates cultured in the presence of NT3 resemble those cultured in the presence of a blocking antibody to BDNF. In both instances, the radius of outgrowth is somewhat decreased, and the fibers are more densely packed. While there is precedence for NT3 acting as a TrkB antagonist, in previous studies such antagonism required extremely high concentrations of NT3 $(20 \mu \mathrm{g} / \mathrm{ml})$ (Dechant et al., 1993). In the granule cell aggregates described here, $1-10 \mathrm{ng} / \mathrm{ml}$ NT3 influenced neurite morphology. This dose is more consistent with NT3 acting as a TrkC receptor agonist.

In summary, we show here that BDNF enhances neurite outgrowth in dissociated and reaggregated granule cell cultures. NT3 does not enhance neurite outgrowth, but does affect the appearance of the axonal halo in aggregate cell cultures in a manner consistent with enhanced fasciculation. The BDNF and NT3 receptors are very similar proteins, with highly conserved tyrosine phosphorylation sites. However, the signaling pathways from these two related receptors must diverge. The different pathways could reflect differences intrinsic to the receptor. Alternatively, immature granule cells may be primed for signaling pathways to enhance neurite outgrowth, while in more mature cells the same signaling pathways might instead influence fasciculation. One method of analyzing how the neurotrophin pathways diverge would be to use activation specific antibodies (Epstein et al., 1992). Antibodies that recognize specific phosphorylation sites of Trk molecules could determine whether the signaling pathways diverge at the receptor, and whether the Trk phosphorylation pattern and the biological effects of activation are intrinsic to the receptor, or depend on the cellular milieu.

\section{References}

Altman J (1972a) Postnatal development of the cerebellar cortex in the rat. J Comp Neurol 145:353-398.

Altman J (1972b) Postnatal development of the cerebellar cortex in the rat. III. maturation of the components of the granular layer. J Comp Neurol 145:465-514.

Ausubel A, Brent R, Kingston RE, Moore D, Seidman JG, Smith JA, Struhl K, eds (1989) Protocols in molecular biology. New York: Wiley.

Baptista C, Hatten M, Blazeski R, Mason C (1994) Cell-cell interactions influence survival and differentiation of purified purkinje cells in vitro. Neuron 12:243-260.

Barbacid M (1993) Nerve growth factor: a tale of two receptors. Oncogene 2033-2041.

Barbacid M, Lamballe F, Pulido D, Klein R (1991) The trk family of tyrosine protein kinase receptors. Biochim Biophys Acta 1072:115127

Barde YA (1989) Trophic factors and neuronal survival. Neuron 2:1525-1534.

Barde YA, Edgar D, Thoenen H (1982) Purification of a new neurotrophic factor from mammalian brain. EMBO J 1:549-553.

Barker P, Shooter E (1994) Disruption of NGF binding to the low affinity neurotrophin receptor p75LNTR reduces NGF binding to TrkA on PC12 cells. Neuron 13:203-215.

Bartel DP, Sheng M, Lao LF, Greenberg ME (1989) Growth factors and membrane depolarization activate distinct programs of early response gene expression: dissociation of fos and jun response. Genes Dev 3:304-313.

Birren SJ, Lo L, Anderson DJ (1993) Sympathetic neuroblasts undergo a developmental switch in trophic dependence. Development 119: 597-610.

Bottenstein JE (1985) Growth and differentiation of neural cells in defined media. In: Cell culture in the neurosciences (Bottenstein JE, Sato G, eds), pp 3-44. New York: Plenum. 
Buchman VL, Davies AM (1993) Different neurotrophins are expressed and act in a developmental sequence to promote the survival of embryonic sensory neurons. Development 118:989-1001.

Burgoyne RD, Cambray-Deakin MA (1988) The cellular neurobiology of neuronal development: the cerebellar granule cell. Brain Res Rev 13:77-101

Caceres A, Banker G, Stewart O, Binder L, Payne M (1984) MAP2 is localized to the dendrites of hippocampal neurons which develop in culture. Dev Brain Res 13:314-318.

Chao M (1992) Neurotrophin receptors: a window into neuronal differentiation. Neuron 9:583-593.

Chitnis AB, Kuwada JY (1990) Axonogenesis in the brain of zebrafish embryos. J Neurosci 10:1892-1905.

Cohen A, Bray G, Aguayo A (1994) Neurotrophin4/5 (NT4/5) increases adult rat retinal ganglion cell survival and neurite outgrowth in vitro. I Neurobiol 25:953-959.

Davies AM, Thoenen H, Barde YA (1986) The response of chick sensory neurons to brain-derived neurotrophic factor. J Neurosci 6:18971904.

Dechant G, Biffo S, Okazawa H, Kolbeck R, Pottgiesser J, Barde YA (1993) Expression and binding characteristics of the BDNF receptor chick trkB. Development 119:545-558.

Druker BJ, Mamon, Roberts TM (1989) Oncogenes, growth factors and signal transduction. $N$ Engl J Med 321:1383-1391.

Epstein RJ, Druker BJ, Roberts TM, Stiles CD (1992) Synthetic phosphopeptides immunogens yield activation specific antibodies to erbB-2 receptor. Proc Natl Acad Sci USA 89:10435-10439.

Friedman WJ, Olson L, Persson H (1991) Temporal and spatial expression of NGF receptor mRNA during postnatal rat brain development analyzed by in situ hybridization. Dev Brain Res 63:43-51.

Furley A, Morton S, Manalo D, Karagogeos D, Dodd J, Jessell T (1990) The axonal glycoprotein TAG-1 is an immunoglobulin superfamily member with neurite outgrowth-promoting activity. Cell 61:157-170.

Gao WQ, Heintz N, Hatten ME (1991) Cerebellar granule cell neurogenesis is regulated by cell-cell interactions in vitro. Neuron 6:705715.

Gao WQ, Liu XL, Hatten ME (1992) The weaver gene encodes a nonautonomous signal for CNS neuronal differentiation. Cell 68:841854.

Ghosh A, Carnahan J, Greenberg ME (1994) Requirement for BDNF in activity-dependent survival of cortical neurons. Science 263:16181623.

Goslin K, Schreyer DJ, Skene JHP, Banker G (1988) Development of neuronal polarity: GAP-43 distinguishes axonal from dendritic growth cones. Nature 336:672-674.

Hantzopoulos P, Suri C, Glass D, Goldfarb M, Yancopoulos G (1994) The low affinity NGF receptor, p75, can collaborate with each of the Trks to potentiate functional response to the neurotrophins. Neuron 13:187-201.

Hatten ME (1985) Neuronal regulation of astroglial morphology and proliferation in vitro. J Cell Biol 100:384-396.

Hatten ME (1993) The role of migration in central nervous system neuronal development. Curr Opinion Neurobiol 3:38-44.

Hawkes R (1992) Antigenic markers of cerebellar modules in the adult mouse. Biochem Soc Trans 20:391-395.

Hempstead BL, Rabin SJ, Kaplan L, Reid S, Parada LF, Kaplan DR (1992) Overexpression of the trk tyrosine kinase rapidly accelerates nerve growth factor-induced differentiation. Neuron 9:883-896.

Hirokawa N, Glicksman MA, Willard MB (1984) Organization of mammalian neurofilament polypeptides within the neuronal cytoskeleton. J Cell Biol 98:1523-1536.

Hofer M, Pagliusi SR, Hohn A, Leibrock J, Barde YA (1990) Regional distribution of brain-derived neurotrophic factor mRNA in the adult mouse brain. EMBO J 9:2459-2464.

Ignelzi M, Miller D, Soriano P, Maness P (1994) Impaired neurite outgrowth of src-minus cerebellar neurons on the cell adhesion molecule L1. Neuron 12:873-884.

Jande SS, Maler L, Lawson DEM (1981) Immunohistological mapping of vitamin $D$-dependent calcium binding protein in the brain. Nature 294:765-767.

Jones KR, Farinas I, Backus C, Reichardt LF (1994) Targeted disruption of the BDNF gene perturbs brain and sensory neuron development but not motor neuron development. Cell 76:989-999.

Klein R, Conway D, Parada LF, Barbacid M (1990) The trkB tyrosine kinase gene codes for a second neurogenic receptor that lacks the catalytic kinase domain. Cell 61:647-656.

Knusel B, Winslow JW, Rosenthal A, Burton LE, Seid DP, Nikolics K, Hefti F (1991) Promotion of central cholinergic and dopaminergic neuron differentiation by brain-derived neurotrophic factor but not neurotrophin-3. Proc Natl Acad Sci USA 88:961-965.

Koizumi H, Contreras ML, Matsuda Y, Hama T, Lazarovici P, Guroff G (1988) K-252a: a specific inhibitor of the action of nerve growth factor on PC12 cells. J Neurosci 8:715-721.

Kosik KS, Finch EA (1987) MAP2 and tau segregate into dendritic and axonal domains after the elaboration of morphologically distinct neurites: an immunocytochemical study of cultured rat cerebrum. $\mathbf{J}$ Neurosci 7:3142-3153.

Lamballe F, Tapley P, Barbacid M (1993) TrkC encodes multiple neurotrophin-3 receptors with distinct biological properties and substrate specificities. EMBO J 12:3083-3094.

Leingartner A, Heisenberg CP, Kolbeck R, Thoenen H, Lindholm D (1994) Brain-derived neurotrophic factor increases neurotrophin-3 cxprcssion in cercbcllar granule ncurons. J Biol Chem 269:828-830.

Lemmon V, Burden S, Payne H, Elmslie G, Hlavin M (1992) Neurite growth on different substrates: permissive versus instructive influences and the role of adhesive strength. J Neurosci 12:818-826.

Levi-Montalcini R, Angeletti PU (1968) Nerve growth factor. Physiol Rev 48:534-569.

Levin B, Dunn-Meynell A (1993) Regulation of growth-associated protein-43 (GAP-43) mRNA associated with plastic change in the adult rat barrel receptor complex. Mol Brain Res 18:59-70.

Lindholm D, Dechant G, Heisenberg CP, Thoenen H (1993) Brainderived neurotrophic factor is a survival factor for cultured rat cerebellar granule neurons and protects them against glutamate-induced neurotoxicity. Eur J Neurosci 5:1455-1464.

Lochter A, Schachner M (1993) Tenascin and extracellular matrix glycoproteins; from promotion to polarization of neurite growth in vitro. J Neurosci 13:3986-4000.

Maisonpierre PC, Belluscio L, Friedman B, Alderson RF, Wiegand SJ, Furth ME, Lindsay RM, Yancopoulos GD (1990) NT-3, BDNF and NGF in the developing rat nervous system: parallel as well as reciprocal patterns of expression. Neuron 5:501-509.

Matus A (1988) Microtubule-associated proteins: their potential role in determining neuronal morphology. Annu Rev Neurosci 11:29-44.

Miale IL, Sidman RL (1961) An autoradiographic analysis of histogenesis in the mouse cerebellum. Exp Neurol 4:277-296.

Middlemas DS, Lindberg RA, Hunter T (1991) TrkB, a neural receptor protein-tyrosine kinase: evidence for a full length and two truncated receptors. Mol Cell Biol 11:143-153.

Rabizadeh S, Oh J, Zhong LT, Yang J, Bitler CM, Butcher LL, Bredesen DE (1993) Induction of apoptosis by the low-affinity NGF receptor. Science 261:345-348.

Raffioni S, Bradshaw RA, Buxser SE (1993) The receptors for nerve growth factor and other neurotrophins. Annu Rev Biochem 62:823850.

Schalleman GC, Gibbs L, Lanahan AA, Claude P, Bothwell M (1988) Expression of NGF receptor in the developing and adult primate central nervous system. J Neurosci 8:860-873.

Segal RA, Takahashi H, McKay RD (1992) Changes in neurotrophin responsiveness during the development of cerebellar granule neurons. Neuron 9:1041-1052.

Sieber-Blum M (1991) Role of the neurotrophic factor BDNF and NGF in the commitment of pluripotent neural crest cells. Neuron 6:949955.

Snedecor GW, Cochran WG (1980) Statistical methods. Ames: Iowa State UP.

Tapley P, Lamballe F, Barbacid M (1992) K252a is a selective inhibitur of the tyrosine protein kinase activity of the trk family of oncogenes and neurotrophin receptors. Oncogene 7:371-381.

Tessarollo L, Tsoulfas P, Martinzanca D, Gilbert DJ, Jenkins NA, Copeland NG, Parada LF (1993) TrkC, a receptor for neurotrophin-3, is widely expressed in the developing nervous system and in nonneuronal tissues. Development 118:463-475.

Valenzuela DM, Maisonpierre PC, Glass DJ, Rojas E, Nunez L, Kong Y, Gies DR, Stitt TN, Ip NY, Yancopoulos GD (1993) Alternative forms of rat trkC with different functional capabilities. Neuron 10 : 963-974.

Verdi J, Anderson D (1994) Neurotrophins regulate sequential changes 
in neurotrophin receptor expression by sympathetic neuroblasts. Neuron 13:1359-1372.

Verdi J, Birren S, Ibanez C, Persson H, Kaplan D, Benedetti M, Chao M, Anderson D (1994) p75LNGFR regulates Trk signal transduction and NGF-induced neuronal differentiation in MAH cells. Neuron 12: 733-745.

Williams E, Walsh F, Doherty P (1994) Tyrosine kinase inhibitors can differentially inhibit integrin-dependent and CAM-stimulated neurite outgrowth. J Cell Biol 124:1029-1037.
Wyatt S, Davies AM (1993) Regulation of expression of mRNA's encoding the nerve growth factor receptors $\mathrm{p} 75$ and TrkA in developing sensory neurons. Development 119:635-648.

Yan Q, Johnson EM Jr (1988) An immunohistochemical study of the nerve growth factor receptor in developing rats. J Neurosci 8:3481-

Zou J-Y, Rabin RA, Pentney RJ (1993) Ethanol enhances neurite outgrowth in primary cultures of rat ccrcbcllar macroncurons. Dcv Brain Res 72:75-84. 